\title{
Failure of Tobacco Control in Central Europe
}

\author{
Manfred Neuberger*
}

Medical University of Vienna, Austria

\begin{abstract}
Failure of tobacco control in Europe is mainly due to lack of enforcement of smoke-free workplaces and public places, low tobacco tax and price, easy access of cigarettes for adolescents, and public smoking visible to children as the normal adult behavior. Driving force behind alibi laws without implementation is the corruption by the tobacco industry. An example of an EU member country is given, where tobacconists distribute the newspapers and the government resists amendments of the tobacco law to meet article 5.3 and article 8 of the Framework Convention on Tobacco Control. This WHO convention should be included in binding directives of the European Union.
\end{abstract}

\section{Tobacco Legislation}

In recent years progress was made in tobacco control, mainly in Australia\& New Zealand, North America and some countries of the developing world, e.g. Brazil, Paraguay, Thailand, and Turkey. Despite of attempts to harmonize regulations of tobacco products in the European Union, tobacco legislation in Europe stayed inhomogeneous [1]. Commissioner Andor did not use his power to make all workplaces smoke-free and commissioner Dalli was dismissed after having drafted a tobacco product directive. He was accused of secret negotiations with the Swedish tobacco industry by the EU anti-fraud office OLAF, but he denied and pointed to the fact that the directive had been delayed by the staff of president Barroso, who forced him to resign. Dalli's successor Borg presented a draft directive, which improves health warnings and limits flavoring of cigarettes attracting children [2]. Hopefully picture warnings will be supplemented by the telephone number of the national quitline on each package and by a hologram to enable backtracking of cigarettes from the black market to the source. At present no mandatory plain packaging (like in Australia), no display ban (like in Iceland since 2001, followed by Canada, Australia, Thailand, Ireland, Norway, Finland, New Zealand, and United Kingdom), no advertising ban at point of sale (not even when selling cigarettes together with school books, comics, stickers, sweets, soft drinks and other goods for children), no ban of vending machines for cigarettes and no raise of age limit to 18 years for buying tobacco is foreseen for all member countries of the EU.

\section{Deficits of Tobacco Control}

The main obstacle against improvement of tobacco control in the $\mathrm{EU}$ is the subsidiarity principle in public health. The Green Paper of the EU towards a Europe free from tobacco smoke showed policy options [3]. 24 ministers of health voted on November 30, 2009 in favor of implementing the WHO Framework Convention on Tobacco Control (FCTC) until 2012, but not the representatives of Austria, Czech Republic and Slovak Republic [4]. Up to now the implementation of FCTC and the EU Council Recommendation on Smoke-free Environments is voluntary [5]. Despite of the ratification of the FCTC treaty nonsmoker's protection is rather poor in the countries of Central Europe, where the influence of the tobacco industry has a long tradition. In Central and Eastern Europe tobacco taxes and cigarette prices are much lower than in Northern and Western Europe. In a European ranking according to tobacco price increase by taxes, smoking restrictions at work and in public places, consumer information, tobacco advertising bans, health warnings and access to smoking cessation therapy, Austria and Greece had the poorest score, followed by Luxembourg, Czech Republic, Hungary and Germany [6]. Recently the tobacco laws of
Hungary, Greece, Luxembourg, and parts of Germany were improved and the Czech minister of health announced to ban smoking in restaurants and bars, while Austria seems to become the ash-tray of Europe.

\section{Austria, the Ash-tray of Europe}

In Austria cigarettes are available around the clock, easier than staple foods, and thousands of vending machines circumvent advertising bans and pretend to be "child-proof". Legally cigarettes can be bought at age 16 , but at age 15 already $18 \%$ of boys and $21 \%$ of girls are smoking daily [7]. This percentage further increases to $35 \%$ in boys and $30 \%$ in girls at age 17. Tobacco tax is also collected from under aged, but not reinvested into tobacco prevention [8]. Austria introduced smoke-free workplace legislation in 2001 (with the exception of the hospitality industry), but at a survey in $2006-2007$ only $72 \%$ of non-smokers reported a smokefree or nearly smoke-free workplace, $5 \%$ suffered from daily passive smoking for $>5$ hours per day, $8 \%$ for $1-5$ hours per day, $12 \%$ for $<1$ hour per day and $3 \%$ worked at home, where $10 \%$ of the nonsmokers reported passive smoking [9]. A ban of smoking in public buildings in 2005 was not enforced and only compulsory schools became smokefree in 2006. It was not before 2009 that sanctions for violations of nonsmoker protection were introduced and the hospitality industry was obliged to provide non-smoking rooms, except for small, single-room enterprises. In premises below $50 \mathrm{~m}^{2}$ the innkeeper still can choose to be a smoking inn if he puts up a sign. Owners of $>50$ up to $80 \mathrm{~m}^{2}$ may apply for the same exemption at the building inspection. As expected, most small restaurants remained smoking for fear of losing guests to neighboring smoking restaurants. Even inns $>80 \mathrm{~m}^{2}$ were allowed to stay without separation until mid-2010. Afterwards they were required to "prevent smoke to enter the non-smoking section", but the law does not give detailed instructions and is not enforced. Neither the police nor work inspectors nor food inspectors are allowed to control smoking in the hospitality industry. Reporting of violations is left to guests only, but they would have to show proofs by taking photos and knowing

*Corresponding author: Manfred Neuberger, Medical University of Vienna, Austria, E-mail: manfred.neuberger@meduniwien.ac.at

Received February 21, 2013; Accepted March 21, 2013; Published March 23 , 2013

Citation: Neuberger M (2013) Failure of Tobacco Control in Central Europe. Occup Med Health Aff 1: 109. doi:10.4172/omha.1000109

Copyright: ( 2013 Neuberger M. This is an open-access article distributed under the terms of the Creative Commons Attribution License, which permits unrestricted use, distribution, and reproduction in any medium, provided the original author and source are credited. 
the name of the violator. As a rule persons are discouraged to make a second report and penalties are rare.

Independent research institutions and in particular health professionals protested against the weak tobacco law which does not comply with the WHO framework convention (ratified by Austria in 2005). Non-smoking rooms adjacent to smoking rooms were found contaminated with tobacco smoke, characterized by nicotine, particulate matter below $2.5 \mu \mathrm{m}$ aerodynamic diameter (PM2.5), and ultrafine particles in dangerous concentrations [10-12]. Nevertheless representatives of the tobacco industry try to avert any legal changes, which could reduce tobacco consumption. Efforts of the Austrian Medical Association to reduce tobacco smoke in public areas were undermined by the Austrian chamber of commerce. Scientific results have been ignored by politicians in charge of implementing the tobacco law. Instead "public opinion" surveys, commissioned by economical interest groups, were used to argue, that the majority of the Austrian population would oppose a total smoking ban. Independent research indicated the opposite (that the majority of the Austrian population would approve a total smoking ban) and that in other European countries a increase of approval was observed after implementation of the ban [13]. By contrast, both employees and guests of the hospitality industry keep complaining in countries with partial bans and the protection of non-smokers (including children) failed.

\section{Conclusion}

An EU directive is urgently needed, which should harmonize tobacco legislation to Western standard.

\section{References}

1. http://eur-lex.europa.eu/LexUriServ/LexUriServ.do?uri=OJ:L:2001:194:0026:0 034:EN:PDF

2. http://ec.europa.eu/health/tobacco/docs/com_2012_788_en.pdf

3. http://ec.europa.eu/health/ph_determinants/life_style/Tobacco/Documents/ gp_smoke_en.pdf

4. http://whqlibdoc.who.int/publications/2003/9241591013.pdf

5. http://eur-lex.europa.eu/LexUriServ/LexUriServ.do?uri=OJ:C:2009:296:0004:0 014:EN:PDF

6. http://www.krebshilfe.de/fileadmin/Inhalte/Downloads/PDFs/Kampagnen/ TCS 2010 Europe.pdf

7. http://praevention.at/upload/documentbox/hbsc_schuelerbericht2010_ barrierefrei1\%5B1\%5D.pdf

8. Neuberger M, Pock M (2009) [Government earnings from cigarette smoking of adolescents in Austria]. Wien Klin Wochenschr 121: 510-514.

9. http://www.statistik.at/web_de/dynamic/statistiken/gesundheit/publdetail?id=4 \&listid $=4$ \&detail $=457$

10. Gorini G, Moshammer H, Sbrogiò L, Gasparrini A, Nebot M, et al. (2008) Italy and Austria before and after study: second-hand smoke exposure in hospitality premises before and after 2 years from the introduction of the Italian smoking ban. Indoor Air 18: 328-334.

11. http://www.mdpi.com/2073-4433/2/2/171/

12. Neuberger M, Moshammer H, Schietz A (2013) Exposure to ultrafine particles in hospitality venues with partial smoking bans. J Expo Sci Environ Epidemiol (in press).

13. http://ec.europa.eu/health/ph_determinants/life_style/Tobacco/Documents/ eb 253 en.pdf
Citation: Neuberger M (2013) Failure of Tobacco Control in Central Europe. Occup Med Health Aff 1: 109. doi:10.4172/omha.1000109
Submit your next manuscript and get advantages of OMICS Group submissions

Unique features:

- User friendly/feasible website-translation of your paper to 50 world's leading languages

Audio Version of published paper

Digital articles to share and explore

Special features:

250 Open Access Journals

20,000 editorial team

21 days rapid review process

Quality and quick editorial, review and publication processing

Indexing at PubMed (partial), Scopus, DOAJ, EBSCO, Index Copernicus and Google Scholar etc

Sharing Option: Social Networking Enabled

Authors, Reviewers and Editors rewarded with online Scientific Credits

- Better discount for your subsequent articles

Submit your manuscript at: www.omicsonline.org/submission/ 